\title{
CENTURY-LONG DYNAMICS OF THE LAND USE STRUCTURE IN THE UNITED STATES
}

\author{
Valerij N. Minat \\ Ryazan State Agrotechnological University named after P.A. Kostychev, Ryazan, Russian Federation
}

\begin{abstract}
The paper studies the experience of American land use in the twentieth century on the territory of 48 contiguous continental states. Changes in time and space (dynamics) of the main indicators of distribution and use of land resources that form the structural appearance of the U.S. land fund are shown. Based on the analysis of the countrys land use structure, the resulting part of which is a summary table, the periodic dynamics of the land use structure (in twenty-year time intervals) is considered, and the dependence of structural changes in land use on the level and nature of the socio-economic development of American society is shown. The study of the age-old dynamics of structural features of American land use conducted on the basis of scientific materials of American scientists and data from official American statistics makes it possible to draw generalizing conclusions about the nature of land use in the United States, both in the whole country and in the regional aspect. As a result, the author has obtained a generalized scientific picture of how the structure of land use in the continental part of the country (without Alaska) has changed over the course of a century in the direction from maximum to optimal use of natural resources.

Key words: nature management, land use in the United States, spatial and temporal basis of land use, structure and dynamics of land use, U.S. land fund.

Citation. Minat V.N. Century-Long Dynamics of the Land Use Structure in the United States. Journal of Volgograd State University. Economics, 2020, vol. 22, no. 2, pp. 220-231. (in Russian). DOI: https://doi.org/10.15688/ ek.jvolsu.2020.2.21
\end{abstract}

УДК 332.3(73)

ББК 65.32-5; 65.6:65.9(4/8)

Дата поступления статьи: 28.02.2020

Дата принятия статьи: 16.03 .2020

\section{ВЕКОВАЯ ДИНАМИКА СТРУКТУРЫ ЗЕМЛЕПОЛЬЗОВАНИЯ В США}

\author{
Валерий Николаевич Минат \\ Рязанский государственный агротехнологический университет им. П.А. Костычева, \\ г. Рязань, Российская Федерация
}

\begin{abstract}
Аннотация. Исследован опыт американского землепользования в ХХ столетии на территории 48 смежных континентальных штатов. Показаны изменения во времени и пространстве (динамика) основных показателей распределения и использования земельных ресурсов, формирующих структурный облик земельного фонда США. На основе проведенного анализа структуры землепользования страны, результирующей частью которого является сводная таблица, рассмотрена периодичная динамика структуры землепользования (в двадцатилетних интервалах времени), показана зависимость структурных изменений в использовании зем근 ли от уровня и характера социально-экономического развития американского общества. Исследование векоฮิ вой динамики структурных особенностей американского землепользования, проведенное на основе научғі ных материалов американских ученых и данных официальной американской статистики, позволило сделать ю обобщающие выводы о характере землепользования в США как в целом по стране, так и в региональном 㘹 аспекте. В результате авторы получили обобщенную научную картину того, как на протяжении столетия менялась структура использования земли в континентальной части страны (без Аляски) в направлении от () максимального к оптимальному природопользованию.
\end{abstract}


Ключевые слова: природопользование, землепользование в США, пространственно-временные основы землепользования, структура и динамика землепользования, земельный фонд США.

Цитирование. Минат В. Н. Вековая динамика структуры землепользования в США // Вестник Волгоградского государственного университета. Экономика. - 2020. - Т. 22, № 2. - С. 220-231. - DOI: https://doi.org/ 10.15688/ek.jvolsu.2020.2.21

\section{Введение}

Характер землепользования и структура земельных ресурсов Соединенных Штатов Америки на протяжении XX столетия в своей динамике достаточно четко отражали характер и структуру хозяйственной деятельности населения страны. При этом возникали характерные проблемы использования земельного фонда страны. Постепенно уже к середине столетия на первый план вышла проблема охраны и мелиорации земель в тех районах, где был хищнически уничтожен лес, наблюдалось чрезмерное стравливание пастбищ или земля была истощена в результате использования неправильной агротехники. С начала 60-х гг. в ряде районов США остро встала проблема контроля за тем, чтобы добыча полезных ископаемых не приводила к порче земли. Еще через десятилетие особое место заняла проблема оптимального землепользования в районах наибольшей плотности населения, как, например, вокруг гигантских городов. А в 80-х гг. американцы на национальном уровне озаботились проблемой рационального использования земли и сохранения естественного природного ландшафта. К концу столетия в сфере землепользования США как никогда прежде остро встал вопрос об обязательствах (принятых с большим опозданием) перед будущими поколениями по сбережению национального земельного фонда.

На рубеже веков американцы хорошо усвоили практические уроки вековой динамики землепользования, главным из которых выступает нарастающее несоответствие между ограниченными земельными ресурсами - с одной стороны, а с другой - постоянным ростом населения страны (неуклонно растущее потребление), повышением экономической активности общества, расширением урбанизации и хозяйственной инфраструктуры, концентрации и сверхконцентрации «всего и вся» в рамках ограниченного пространства. Поэтому, несмотря на то что земельные ресурсы США и в начале XXI в. все также велики, как и на всем протяжении предыдущего столетия, в современной экономике стал абсолютно доминировать ответственный (можно сказать, сверхрациональный) подход к их использованию. Население страны достаточно велико, быстро растет и, что важнее всего, концентрируется в определенных районах, где конкурентная борьба за землю в очередной раз перекраивает структуру землепользования и создает тем самым новые, еще более серьезные проблемы не только продуктивного, но и оптимального использования земель различного назначения.

Однако не только (и не столько) размеры земельного фонда страны, вовлекаемого в хозяйственную деятельность, а прежде всего структура землепользования, характерная для США в тот или иной период социальноэкономического развития, изменения в распределении земель между землепользователями, происходившие с течением времени, определили практическую значимость и сам характер использования американской земли в XX столетии.

Структура землепользования и продуктивность земельного фонда всегда находились и находятся в тесной взаимосвязи с самим производством, неотторжимы от него и диалектически включены в процесс расширенного воспроизводства, независимо от характера общественно-экономических отношений, времени и пространства. В связи с этим исследование динамики структурных изменений американского землепользования, наблюдаемой в течение XX в., имеет значение для изучения аналогичных процессов в России, прошедшей в этом столетии сложный путь от Империи через систему Советов до Федерации. При этом в нашей стране всегда остро стоял земельный вопрос, перманентно вызывавший всплески реформ в российском обществе. 


\section{Материалы и методы исследования}

Потенциал земельных ресурсов страны исчисляется как произведение их фактических физических объемов на фактический или достигнутый в мировой практике нормативный уровень их использования. Нижняя граница этого потенциала - это сами фактические размеры общей площади земельных ресурсов страны, используемые по прямому назначению [Родин и др., 2018].

Земли в Соединенных Штатах действительно не так уж мало. Общая площадь 48 смежных штатов (без Аляски и Гавайев) составляет 3 млн кв. миль ${ }^{1}$, или 1,9 млрд акров $^{2}$. Включение Аляски и Гавайских островов увеличивает общую территорию США с 1,9 млрд до 2,27 млрд акров. Гавайские острова фактически добавляют лишь 4,1 млн акров, но Аляска - самый большой штат (365 млн акров, тогда как площадь второго по величине штата Техас равна 168 млн акров, а Калифорнии - 100 млн акров) [Statistical Abstract ..., 2001; U.S. National Land ... , 2020]. Таким образом, включение Аляски существенно влияет на расчеты и выводы, связанные с общей земельной площадью. Более того, на Аляске велики пространства «непродуктивной» земли, а картина землевладения настолько необычна, что добавление данных об Аляске к сведениям по 48 сопредельным штатам существенно отразится на среднестатистической картине по стране. Поэтому эти два «несопредельных» штата исключены из нашего рассмотрения.

Конечно, какая-то часть исследуемой территории классифицируется как «бедленд (badlands)» ${ }^{3}$, к числу которого относится «непродуктивная, бесплодная земля». Точное определение «непродуктивной» или «бросовой» земли заметно меняется от района к району в зависимости от экономических, социальных и технологических условий. Это затрудняет проведение сравнений в международном масштабе, но не делает их невозможными, если они проводятся в самом общем виде. Количество действительно «бросовой» земли в США в 2000 г. составляло лишь около 10 \% площади страны, то есть относительно небольшую долю по сравнению, скажем, с Канадой (58 \%) или среднемировой цифрой, составлявшей в указанный год $45 \%$ [Bureau of Land ... , 2020]. На каждого американца приходилось до 9 акров земли, которую можно так или иначе продуктивно использовать. Для сравнения укажем, что соответствующая цифpa, например, для Великобритании составляла в 2000 г. менее одного акра. Даже площадь той земли, которая использовалась на фермах США в среднем в течение всего XX в. (этот расчетный показатель составляет 1,1 млрд акров, что ниже зарегистрированного максимума и значительно меньше той площади, которая при современной технике способна давать продовольствие), составляла в расчете на каждого американца свыше 5 акров. Это положение также резко отличало в сложившейся ситуации США от других развитых стран на протяжении всего рассматриваемого периода времени.

Важно отметить, что в настоящее время не сложилось полной статистической базы и согласованной методики анализа, классификации и оценки имеющихся данных, что дало бы возможность сопоставлять их как во времени, так и в пространстве, по отдельным территориям, выделенным Бюро цензов США 4 . Даже когда речь идет об использовании земли для сельскохозяйственных целей и лесозаготовок, где уже давно проводится сбор статистической информации, отсутствуют общепринятые методы классификации, и цифры меняются в зависимости от периода времени и от места к месту в соответствии с суждениями и текущей практикой того органа, который ведает сбором данных. Надо признать, что существуют трудности в отношении того, куда при классификации видов использования земли в сельском хозяйстве или в лесоводстве следует точно отнести тот или иной участок земли, но можно было бы с полным основанием ожидать единообразного подхода, по крайней мере в официальной практике.

Однако наибольшую тревогу вызывают пробелы в статистических данных, относящихся к другим видам использования земли, не связанным с сельским и лесным хозяйством. Они часто требуют небольшой площади, но многие из них имеют важнейшее значение для жизни страны и ее экономики, и их потребности в земле привлекают все большее внимание. Статистические данные о них очень 
В.Н. Минат. Вековая динамика структуры землепользования в США

скудны, а имеющаяся информация отражает способы их сбора и истолкования лицами или заинтересованными органами и обычно трудно сопоставима.
Сводная таблица, отражающая динамику структуры землепользования в 48 смежных континентальных штатах США в течение всего XX в., представленная в настоящем

Динамика структуры землепользования в 48 смежных штатах США в XX в.,

Таблица млн акров

\begin{tabular}{|c|c|c|c|c|c|c|c|c|c|c|c|c|c|}
\hline & \multicolumn{2}{|c|}{1900 г. } & \multicolumn{2}{|c|}{1920 г. } & \multicolumn{2}{|c|}{1940 г. } & \multicolumn{2}{|c|}{1960 г. } & \multicolumn{2}{|c|}{1980 г. } & \multicolumn{2}{|c|}{2000 г. } \\
\hline & & $\begin{array}{l}\text { пло- } \\
\text { щадь }\end{array}$ & $\%$ & $\begin{array}{l}\text { пло- } \\
\text { щадь }\end{array}$ & $\%$ & $\begin{array}{l}\text { пло- } \\
\text { щадь }\end{array}$ & $\%$ & $\begin{array}{l}\text { пло- } \\
\text { щадь }\end{array}$ & $\%$ & $\begin{array}{l}\text { пло- } \\
\text { щадь }\end{array}$ & $\%$ & $\begin{array}{c}\text { пло- } \\
\text { щадь } \\
\end{array}$ & $\%$ \\
\hline \multirow{4}{*}{ 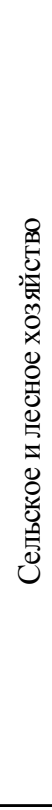 } & $\begin{array}{l}\text { Земля, за- } \\
\text { нятая зер- } \\
\text { новыми, } \\
\text { включая } \\
\text { временные } \\
\text { пастбища }\end{array}$ & 396 & 20,8 & 480 & 25,2 & 467 & 24,5 & 447 & 23,5 & 443 & 23,3 & 476 & 25,0 \\
\hline & \begin{tabular}{|l} 
Пастбища \\
фермер- \\
ских хо- \\
зяйств и \\
лугопаст- \\
бищные \\
угодья, не \\
принадле- \\
жащие \\
фермерам \\
\end{tabular} & 808 & 42,2 & 730 & 38,3 & 740 & 38,9 & 700 & 36,8 & 700 & 36,8 & 700 & 36,8 \\
\hline & \begin{tabular}{|l|} 
Непахот- \\
ная земля \\
ферм
\end{tabular} & 53 & 2,8 & 58 & 3,0 & 44 & 2,3 & 45 & 2,4 & 45 & 2,4 & 45 & 2,4 \\
\hline & $\begin{array}{l}\text { Земля под } \\
\text { коммерче- } \\
\text { ским лесом } \\
\end{array}$ & 525 & 27,6 & 500 & 26,3 & 488 & 25,6 & 484 & 25,4 & 484 & 25,4 & 484 & 25,4 \\
\hline \multirow{5}{*}{ 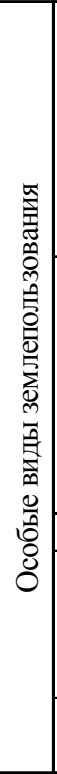 } & $\begin{array}{l}\text { Отдых, ис- } \\
\text { ключая } \\
\text { районы } \\
\text { водохра- } \\
\text { нилищ и } \\
\text { городские } \\
\text { парки } \\
\end{array}$ & 5 & 0,3 & 12 & 0,6 & 41 & 2,2 & 44 & 2,3 & 76 & 4,0 & 134 & 7,0 \\
\hline & \begin{tabular}{|l} 
Города с \\
населением \\
свыше \\
2,5 тыс. \\
чел., вклю- \\
чая город- \\
ские парки \\
\end{tabular} & 6 & 0,3 & 10 & 0,5 & 13 & 0,7 & 21 & 1,1 & 32 & 1,7 & 45 & 2,4 \\
\hline & Транспорт & 17 & 0,9 & 23 & 1,2 & 24 & 1,3 & 26 & 1,4 & 28 & 1,5 & 30 & 1,6 \\
\hline & \begin{tabular}{|l|} 
Заповедни- \\
ки и на- \\
циональ- \\
ные парки \\
\end{tabular} & - & - & 1 & - & 12 & 0,6 & 15 & 0,8 & 18 & 0,9 & 20 & 1,1 \\
\hline & \begin{tabular}{|l|} 
Водохра- \\
нилища \\
\end{tabular} & - & - & 2 & - & 7 & 0,4 & 12 & 0,6 & 15 & 0,8 & 20 & 1,1 \\
\hline \multicolumn{2}{|c|}{$\begin{array}{c}\text { Общая площадь } \\
\text { указанных } \\
\text { земель } \\
\end{array}$} & 1810 & 95,1 & 1816 & 95,4 & 1836 & 96,4 & 1794 & 94,2 & 1841 & 96,7 & 1954 & 97,4 \\
\hline \multicolumn{2}{|r|}{$\begin{array}{c}\text { Остальная } \\
\text { земля }\end{array}$} & 94 & 4,9 & 88 & 4,6 & 68 & 3,6 & 110 & 5,8 & 63 & 3,3 & 50 & 2,6 \\
\hline \multicolumn{2}{|c|}{ Общая площадь } & 1904 & 100,0 & 1904 & 100,0 & 1904 & 100,0 & 1904 & 100,0 & 1904 & 100,0 & 1904 & 100,0 \\
\hline
\end{tabular}

Примечание. Составлено на основе статистических источников, приведенных в соответствующем списке. 
исследовании, составлена на основе различных материалов открытого доступа.

Преимущественное использование статистических и аналитических материалов, положенных в основу анализа структуры землепользования в США в тот или иной период времени (в таблице использован двадцатилетний временной шаг), определяется, прежде всего, полнотой и тщательностью оценки различных земель и их возможного использования. Так, например, аналитические материалы взяты из фундаментальных научных работ авторитетного американского ученого М. Клоусона «Land for the Future» за 19001940 гг.; «Land for Americans» и «The Land System of the United States» за 1950-1960 гг., а, скажем, прогнозы на период 1960-2000 гг. - из книги Г.Г. Ландсберга, Л.Л. Фишмена и Дж.Л. Фишера «Resources in America's Future» [C1awson, 1957; C1awson, 1963; Clawson, 1968; Landsberg et al., 1959]. Bce прогнозные данные, обоснованные американскими исследователями проблем землепользования США во второй половине ХХ в., сопоставлены с материалами многолетней американской статистики (1960-2000 гг.): Statistical Abstract of the United States, U.S. Census of Agriculture и др. [Statistical Abstract ... ; U.S. Census of Agriculture ... ; U.S. Department of Agriculture (1970-2001) ... ; U.S. Department of Agriculture (1936-2001) ... ; U.S. Department of Agriculture (USFS) ... ; U.S. Department of Interior ... ; U.S. National Land ... ] и скорректированы на их основе.

Необходимо заметить, что материалы американской статистики, отражающие характер и структуру использования земли в 1960-1980 гг., демонстрируют последствия длительного действия по методу проб и ошибок, а не результаты тщательной оценки различных земель и их возможного использования. Таким образом, хотя в указанный двадцатилетний период предпринимались меры в целях обеспечения «оптимального» использования земли, участки, наиболее подходящие для какой-либо конкретной цели, не могли быть в реальности использованы по указанному назначению. Иначе говоря, характер использования земельного участка не являлся точным ориентиром в отношении его потенциала. Более того, положение не осталось неизменным, поэтому динамика развития различных видов землепользования представляется нам как наиболее важная характеристика земельных ресурсов США.

В таблице оценки каждой «двадцатилетки» сопоставляются с данными, относящимися к прошлым и будущим периодам, то есть просматривается периодичная динамика структуры землепользования. Однако ясно, что, если даже оценки, относящиеся к последним годам, вызывают некоторое недоверие, тем более нельзя излишне полагаться на оценки, относящиеся к более отдаленным годам и прогнозам на будущее. В некоторых случаях таблица служит целям приблизительной ориентации. К тому же приводимые данные относятся к стране, взятой в целом. Между тем структура использования земли меняется как во времени, так и от места к месту. Ясно, что региональные и местные данные еще более изменчивы и неточны, чем данные по стране в целом. Однако Министерство сельского хозяйства США на протяжении практически всей второй половины XX в. публиковало соответствующие ежегодные оценки (Major Uses of Land and Water in the United States) [U.S. Department of Agriculture ... , 2020], xaрактеризующие виды использования земли в различных сельскохозяйственных районах. Эти данные по мере возможности мы скоррелировали с данными американских ученых, на основе чего рассчитали значение основных показателей, приведенных в таблице и в динамике отражающих структуру землепользования в США в ХХ веке. Тем более что различные по характеру источники дают приемлемую основу для более широкого анализа.

\section{Результаты исследования и их обсуждение}

Размер занимаемой площади не обязательно отражает относительное значение различных видов использования земли. То же самое можно сказать о других возможных критериях, таких как стоимость земли, число занятых в расчете на 1 акр или стоимость продукции на 1 акр. Эти критерии могут преувеличивать значимость менее «землеемких» видов использования, таких, например, как городской транспорт. Для нормального функ- 
ционирования современной экономики и общества все большее значение приобретают различные виды использования земли, и не имеет смысла рассуждать о том, какой из них более важен. Тем не менее поверхностное отношение к тому, что для несельскохозяйственных целей используются дополнительно небольшие площади, может привести к безразличному отношению к оценке потребностей в земле для этих видов ее использования, недопониманию реального значения противоречий между разными видами использования земли в отдельных районах и к терпимости в отношении расточительной эксплуатации земли «мелкими» землепользователями в ущерб тем секторам «крупных» землепользователей, которые используют землю с высокой степенью продуктивности. В связи с этим необходимо обдуманное и реалистическое отношение к каждому виду использования, рассматриваемому на фоне целого.

Так, результаты анализа данных о структуре землепользования в США за период 19201960 гг. позволяют говорить о том, что почти 1,2 млрд акров (приблизительно $63 \%$ общей площади смежных штатов США) на конец указанного периода времени использовались для тех или иных сельскохозяйственных целей (хотя не обязательно фермерами) [Taylor et al., 1994]. Еще 25 \% площади классифицируются как земли под лесами коммерческого значения, так что на все остальные виды использования в 1960 г. приходилось лишь около 12 \% общей площади [Kellogg et al., 1994].

Среди земель, отнесенных к обширной категории сельскохозяйственных, большую часть (около 700 млн акров) в 1960 г. составляли пастбища [White et al., 1977]. Как и в других классах, сюда входили земли весьма различных типов и уровней плодородия. Некоторые земли могли относительно интенсивно использоваться в качестве пастбищ (например, постоянные пастбища фермерских хозяйств), другие можно было использовать лишь весьма экстенсивно (в частности, бедные федеральные земли, используемые в качестве пастбищ на Западе). Некоторые участки сплошь были покрыты травой, другие поросли лесом, но оставались пригодными для пастьбы. Большая часть такой земли по современным стандартам малопродуктивна, и возможности ее использования ограничены это остаточная земля, которая была выделена под пастбища после того, как были изъяты лучшие земли, пригодные для других целей. Эти пастбищные земли располагались главным образом западнее реки Миссисипи, причем большая часть их входила в состав Федерального земельного фонда.

Как следует из таблицы, количество земли, используемой в этих целях, существенно сократилось в XX столетии, главным образом в течение двух начальных десятилетий (19001920 гг.). Этот факт отражает ее характер как «остаточной земли»: смешанное фермерское хозяйство и другие виды использования земли расширились за счет пастбищ. Использование земли под пастбища часто сочеталось с другими видами ее использования, в частности, в рекреационных целях. Если такие функции начинали преобладать над пастбищным скотоводством, категория использования земли могла быть изменена. Однако полученные нами данные свидетельствуют о том, что изменения, отраженные в динамике землепользования на протяжении всего XX в. (вплоть до 2000 г.), нельзя назвать значительными.

Площадь земель, занятых под посевы и выпасы, составила к 1960 г. почти 1/4 общего земельного фонда [White et al., 1977]. К землям под посевами относят не только участки, с которых снимается урожай, но также угодья, находящиеся под паром, залежью, занятые запашной культурой, а также не давшие урожая в тот год, о котором идет речь. Под выпасами мы подразумеваем землю, которая пригодна под посевы, но в соответствующем году использовалась только для выпаса скота. В 1960 г. такие земли составляли около $1 /{ }_{7}$ всех земель, занятых под посевы и выпасы, то есть несколько меньше, чем раньше [Sturdevant, 1989]. Таблица показывает, что общая площадь земель, используемых под посевы и выпасы, в начале XX в. постепенно росла и достигла максимума за столетний период (около 486 млн акров) примерно в 1930 году. Затем последовало небольшое снижение, связанное не с уменьшением производства сельскохозяйственных продуктов, а с резким ростом продуктивности.

Возникает важный вопрос: в какой степени продолжавшийся на протяжении всего 
векового периода времени рост продуктивности мог удовлетворять спрос растущего населения самих США и потребности заокеанских государств? Данные таблицы отражают резкий рост потребности в земле, занятой зерновыми (включая временные пастбища) в первом двадцатилетнем периоде столетия, затем медленное снижение этого показателя вплоть до 1980 г. и, наконец, стабильный рост потребности в земле под посевы после 1980 года. В результате к 2000 г. общая площадь, пригодная под посевы, составила 476 млн акров, практически сравнявшись с максимальным значением данного показателя, отмеченного за 80 лет до этого (1920 г.).

В то время как общая площадь земли, используемой под посевы и выпасы, на протяжении последних десятилетий XX в. была почти стабильной, ее распределение по регионам страны заметно менялось. В некоторых районах посевная площадь заметно сократилась, особенно с конца 40-х гг. в связи с прекращением обработки худшей земли и изменением характера ее использования. Это сокращение было наибольшим в районах Северных и Южных равнин, но оно затронуло и восточные районы. Значительный рост наблюдался в Кукурузном поясе, но он происходил также в Горных и Тихоокеанских штатах. Эти изменения говорят о большем учете потенциальных возможностей земли, о том, что посевы сосредоточивались на наиболее плодородных землях. Площади под посевами оставались значительными в 50-60-х гг. в штатах Северного Центра. Они преобладали в Кукурузном поясе на Северных равнинах и занимали значительное место в приозерных штатах. В других районах в указанные годы посевы нигде не составляли более $25 \%$ земельной площади, а в Горных и Тихоокеанских штатах, несмотря на некоторый рост в 70-е гг., их доля оставалась относительно невелика и в 1980 г. и в 2000 г. [Эстолл, 1977; Bureau of Land ..., 2020].

Разумеется, площадь земли, взятая сама по себе, представляет собой только один из факторов, определяющих производство зерна. В число других факторов входят плодородие, капиталовложения и организация сбыта. Если учесть все эти условия, то часть посевных площадей во «второстепенных» районах (на- пример, в Тихоокеанских штатах) приобретает исключительную ценность и вносит огромный вклад в общее производство сельскохозяйственной продукции.

В прошлом отношение к занятой лесом земле было, пожалуй, еще хуже, чем к другим ресурсам. Леса часто рассматривались как препятствие на пути освоения земли. По мере того как в течение XIX в. эксплуатация лесных ресурсов приобретала все более коммерческий характер, они расхищались без учета и понимания последствий. Не удивительно, что первые шаги по охране природных ресурсов были связаны именно с лесами. Тем не менее эксплуатация лесных ресурсов в коммерческих целях оставалась на протяжении первой половины XX в. и даже в 1960 г. значительным направлением использования земли, занимающей около 25 \% территории смежных штатов США [Sturdevant, 1989; Lindstrom et al., 1994].

Здесь снова возникают особые проблемы, связанные с расчетами и определениями вследствие, например, существования миллионов участков леса, принадлежащих частным владельцам, и в результате того, что многие земельные участки используются одновременно для различных целей. Но, если детальные данные по районам и менее крупным территориям сомнительны, то цифры по стране в целом, представленные в таблице, по нашему мнению, не далеки от истины. Они говорят о том, что площадь, занятая коммерческими лесами, в XX в. постоянно и неуклонно сокращалась, причем это сокращение также было наиболее значительным перед 1920 годом. Однако наряду с постепенным сокращением общей площади под лесом произошел знаменательный процесс в лесоводстве. В 1900 г. практически ни один акр из 525 млн акров коммерческих лесов не использовался под перманентное лесоразведение, включающее регулярную посадку деревьев, а не просто заготовки по принципу «руби и уходи» [Робинсон, 1990]. К середине ХХ в. лесоразведение практиковалось на $3 / 4$ несколько сократившейся площади лесов [Джингарадзе, 1973]. Практика использования лесных ресурсов в коммерческих целях становилась все более эффективной (в плане комплексной переработки лесных ресурсов) в 1960-2000 годах. Однако 
нельзя с твердой уверенностью утверждать, что площадь коммерческих лесов в США была стабильной (как отражено в нашей таблице) за два последних двадцатилетия XX в. (1960-2000 гг.), поскольку спрос на продукты леса (древесину, фанеру и целлюлозу) в это время практически постоянно превышал предложение. Скорее всего, площадь лесов неуклонно сокращалась под давлением требований использования лесов для других целей, особенно рекреационных и водоснабжения (во всяком случае в конце XX - начале XXI в.). США нуждались в импорте большого количества лесной продукции.

Земли, занятые лесами, на протяжении всего XX столетия представляли собой важный фактор для развития всех районов США за исключением Центральных равнин и Кукурузного пояса. В стране, таким образом, четко различались две лесные зоны - восточная и западная, разделенные территорией, где леса играли менее значительную роль. Запад являлся основным районом коммерческих хвойных лесов, а Восток - источником твердой древесины, но не только ее. Большое значение приобрел тот фактор, что на Западе отмечалась более высокая доля девственных лесов, большая часть которых принадлежала государству (в среднем порядка $3 / 4$ общей площади, занимаемой государственными лесами в США), тогда как на Востоке преобладали леса второй или третьей посадки и площади, занятые лесом, преимущественно находившимся в частной собственности. Вообще земли, на которых располагались государственные леса, получали лучшую заботу, находясь в государственном земельном фонде и только ожидая раздачи тем или иным собственникам согласно законодательству США. Их доля в общих запасах древесины на корню практически во все периоды XX в. была больше (от 65-67 до 55-56 \% в разные периоды), чем их доля в общей площади (всегда приблизительно $40 \%$ ), занятой лесами, где первенство всегда принадлежало «частникам» [Лесное хозяйство США ..., , 2005]. И только в самом конце столетия наметился сдвиг в проведении лесозаготовок с переносом активности с государственных земель на Западе на частные земли на Востоке. При этом на Западе государственные лесные угодья, пример- но как и в начале века, составляли примерно $2 / 3$, а на Востоке - всего лишь $1 / 5$ от всех лесных угодий. В целом география лесов США в $\mathrm{XX}$ столетии характеризовалась такой благоприятной особенностью, как широкое распространение их по территории страны, и особенно в более населенных ее частях.

Сельскохозяйственные земли и леса вместе взятые к концу XX в. занимали $88 \%$ всей земельной площади США [U.S. Department of the Interior ..., 2020]. Остающаяся часть земли, используемая для «специальных целей», имела тем не менее большое значение как сама по себе, так и в отношении ее воздействия на людей и на использование земли вообще. Вдобавок потребности этого сектора в земле, как показано в таблице, постоянно возрастали. Самой большой и заметной категорией являлся отдых, для целей которого использовались все большие площади. Значительная часть этих земель начиная с 40-х гг. постоянно включалась в систему заповедников и национальных парков, которые преимущественно располагались в западных штатах. C ростом национальных парков территории, используемые для рекреационных целей, быстро расширились [National Park ... , 2020]. Стабильный прирост их территории наблюдался в течение всей второй половины XX века. Поскольку в плотно заселенной восточной половине страны условия для отдыха населения всегда были хуже, чем у населения, проживающего на Западе, площади, отведенные для рекреационных целей, здесь значительно расширялись, особенно вблизи больших городов. При этом для отдыха отводилось большое число небольших участков земли, а не обширные пространства, как на Западе. Этот важный вид использования земли нередко совмещался с другими видами, играющими подсобную роль. Значение такого многогранного использования земли, постоянно возрастало, особенно в районах, где земля стоила дорого.

В завершение обсуждения полученных результатов, нельзя не отметить, что в динамике структуры землепользования США и России достаточно хорошо прослеживаются некоторые общие тенденции, сближающие наши огромные по территории страны по характеру и структуре использования земельных ресурсов в те или иные периоды XX в., 
несмотря на целый ряд существенных общественно-экономических и природно-климатических различий. Так, например, средние значения обрабатываемых земель за столетний период времени, рассчитанные по обеим странам, близки. Им свойственна сравнительно невысокая распаханность на уровне свыше $10 \%$ (в России - около 8 \%), так что они в итоге постоянно сосредоточивали более чем по $15 \%$ обрабатываемого клина планеты [U.S. National Land ..., 2020]. Показатель распаханности отчетливо варьируется как в США, так и в России по ландшафтным зонам и в общем нарастает по мере движения к югу. Дерновоподзолистые и подзолистые почвы в зоне хвойных и смешанных лесов в России и на территории Североамериканского материка в границах США на протяжении всего XX столетия в среднем были распаханы только примерно на $6 \%$ площади, а черноземы лесостепи и степи - наполовину. Далее, при продвижении к югу, доля пашни падает по мере усиления засушливости. При этом внутренние контрасты в степени земледельческого освоения в обеих странах не достигают такой силы, как, скажем, в Индии, Китае и Юго-Восточной Азии, прежде всего из-за отсутствия густонаселенных обширных земледельческих районов.

\section{Заключение}

Рассмотренные тенденции динамики структуры землепользования в США за весь период XX столетия в целом заключаются в следующих положениях:

1) в постоянном расширении городских и строительных площадей за счет сельскохозяйственных угодий;

2) в увеличении площадей антропогенного бедленда, в частности бросовых земель, при добыче полезных ископаемых и вторичном засолении;

3) в сокращении площадей естественных лесных пастбищных, а также переувлажненных земель;

4) в вынужденном расширении рекреационных земель, особенно в районах сверхконцентрации урбанизированного населения страны.

В то же время в течение различных периодов XX в. (двадцатилетних и иной продол- жительности) наблюдаются процессы другого характера. Среди них, например, выделяется типичное для конца 60-х - начала 70-х гг. увеличение площади пахотных угодий на севере Великих равнин, прежде всего орошаемых, за счет пастбищных земель и, соответственно, пастбищных - за счет лесных благодаря интенсификации орошения. И, наоборот, на юге Великих равнин в последние двадцать лет прошлого столетия (1980-2000 гг.) отмечалось сокращение орошаемых угодий и расширение пастбищ как следствие начавшегося истощения запасов подземных вод - важнейшего источника орошения в этом районе.

Исходя из анализа данных за столетний период, мы делаем вывод о том, что особенности динамики земельного фонда США в XX в. раскрывают пространственно-временной характер американского землепользования, в основу которого положена, прежде всего, система общественных ценностей, доминирующих в стране. По нашему мнению, американское землепользование по своему характеру и структуре можно обоснованно назвать «слепком» с характера и структуры общественных отношений, испытывающих необходимость все более масштабного государственного регулирования. Трудности учета региональных тенденций в проведенном нами исследовании, а также в отдельных случаях стихийность перестройки земельного фонда в местном масштабе, объясняюся тем, что общенациональные прогнозы, сделанные в 70-х гг., давали расчет площадей различных категорий землепользования, прежде всего через потребности в сельскохозяйственных продуктах и урожайности. В связи с этим они отличались невысокой точностью. Однако используемые нами американские статистические материалы, охватывающие полностью вторую половину XX столетия, в целом подтвердили общую динамику структуры землепользования США в пространственно-временном континууме, соответствующую вышеназванным положениям.

В заключение следует особо подчеркнуть, что к концу XX столетия кризис землепользования (как в плане его характера, так и структуры) охватил не только США, но и Россию со странами бывшего СССР, да и мир в целом. Следовательно, динамично меняюща- 
яся политическая ситуация, изменчивая рыночная конъюнктура и актуальные экономические задачи того или иного периода развития страны и методы их достижения не являются его первопричинами. Главные причины более глубокие, более общие и присутствуют во всех странах и на всех континентах. Анализ векового опыта США в области использования земельных ресурсов указывает на то, что в основе структуры землепользования на всем протяжении ХX в. была заложена потребительская система общественных отношений, подчиненная перманентному циклическому характеру экономики. Она опиралась в основном на рабочую парадигму, сформулированную еще в Древнем Риме: «Максимально использовать даровые силы природы». Объективная реальность заставляла постепенно изменять характер и структуру землепользования одной из передовых (а после Второй мировой войны наиболее развитой) стран от максимального к оптимальному использованию земли. В этом, по нашему мнению, состоит основное практическое значение изучения динамики американского землепользования для изучения подобных процессов, происходивших в нашей стране в ее новейшей истории, и разрешения кризисных проблем в данной области, стоящих перед современной Россией.

\section{ПРИМЕЧАНИЯ}

${ }^{1}$ Квадратная миля составляет 2,59 км².

${ }^{2}$ Акр составляет 0,4047 га.

${ }^{3}$ Бедленд (бэдленд) - резко и сложно расчлененный низкогорный рельеф, состоящий из запутанной сети ветвящихся узких водоразделов, непригоден для хозяйственной деятельности, прежде всего земледелия.

${ }^{4}$ При характеристике географических различий мы берем за основу преимущественно четыре региона (Северо-Восток, Северный Центр, Юг, Запад) и входящие в них девять районов (Новая Англия, Средне-Атлантические штаты, Северо-Восточный Центр, Северо-Западный Центр, Южно-Атлантические штаты, Юго-Восточный Центр, Юго-Западный Центр, Горные штаты, Тихоокеанские штаты) Бюро цензов (United States Census Bureau, Bureau of the Census) как группировки штатов и при необходимости уточняем их данными по отдельным штатам.

\section{СПИСОК ЛИТЕРАТУРЫ}

Джингарадзе, В. 3. Экономическая история США / В. 3. Джингарадзе. - М. : Высш. шк., 1973. $159 \mathrm{c}$.

Смит, В. Б. Лесное хозяйство США в фактах и исторической динамике / В. Б. Смит, Д. Дарр ; Министерство сельского хозяйства США. Лесная служба. FS-846. - [Б. м.] : [б. и.], 2005. - 40 с.

Робинсон, Н. Правовое регулирование природопользования и охрана окружающей среды в США : пер. с англ. / Н. Робинсон. - М. : Прогресс, 1990. -528 с.

Родин, И. К. К проблеме оценки рыночной стоимости земли / И. К. Родин, В. Н. Минат // Донецкие чтения 2018: образование, наука, инновации, культура и вызовы современности : материалы III Междунар. науч. конф. - Донецк : Изд-во ДонНУ, 2018. - С. 337-339.

Эстолл, Р. География Соединенных Штатов Америки: пер. с англ. / Р. Эстолл ; ред. В. М. Гохман. - М. : Прогресс, 1977.-429c.

Clawson, M. Land for Americans / M. Clawson. Chicago : Rand McNally, 1963.-396 p.

Clawson, M. Land for the Future / M. Clawson. - N. Y. : MeGraw Hill, 1957. - 420 p.

C1awson, M. The Land System of the United States / M. Clawson. - Nebraska : University of Nebraska, 1968. - 460 p.

Kellogg, R. L. Highlights from the 1992 National Resources Inventory/ R. L. Kellogg, G. W. TeSelle, J. J. Goebel // J. Soil and Water Conserv. - 1994. - Vol. 49, № 6.P. 521-527.

Landsberg, G. G. Resources in America's Future / G. G. Landsberg, L. L. Fishman, J. L. Fischer.N. Y. : [s. n.], 1959. - 712 p.

Lindstrom, M. J. Management Considerations for Returning CRP Lands to Crop Production / M. J. Lindstrom, T. E. Schumacher, M. L. Blecha // J. Soil and Water Conserv. - 1994. - Vol. 49, № 5. -P. 420-425.

Sturdevant, S. K. Toward a Federal Land Information Systems: Experiences and Issues / S. K. Sturdevant //US Geol. Surv. Bull.-1989. - № 1852.-P. IV, 1-15.

Aggregate Economic Effects of CRP Lands Returning to Production / C. R. Taylor [et al.] // J. Soil and Water Conserv. - 1994. - Vol. 49, № 5. - P. 473-480.

White, G. Regional Geography of the United States / G. White, E. Foscue, T. McKnight. - N. Y. : [s. n.], 1977. -408 p.

Bureau of Land Management. - Electronic text data. Mode of access: https://www.blm.gov (date of access: 24.02.2020). - Title from screen.

National Park Service. - Electronic text data. - Mode of access: https://www.nps.gov/index.htm (date of access: 24.02 .2020 ). - Title from screen. 
Statistical Abstract of the United States 1953-2000. Washington : U.S. Government Printing Office, 1954-2001. - Electronic text data. - Mode of access: https://books.google.ru/books?id= YkXjuVR9iN8C\&hl=ru (date of access: 24.02.2020). - Title from screen.

U.S. Census of Agriculture 1954-2000. United States. Bureau of the Census. Washington : U.S. Government Printing Office, 1957-2003. Electronic text data. - Mode of access: https:// books.google.ru/books?id=sgNIAQAAIAAJ $\& h \mathrm{l}=\mathrm{ru} \&$ source $=\mathrm{gbs} \_$navlinks_s (date of access: 24.02.2020). - Title from screen.

U.S. Department of Agriculture: An official website of the United States government, Economic research service: major land uses in the United States, 1970-2001. - Electronic text data. - Mode of access: https://www.usda.gov (date of access: 24.02.2020). - Title from screen.

U.S. Department of Agriculture: National Agricultural Statistics Service, 1936-2001. - Electronic text data. - Mode of access: https://www.nass.usda. gov/Publications/Ag_Statistics (date of access: 24.02.2020). - Title from screen.

U.S. Department of Agriculture: United States Forest Service (USFS). - Electronic text data. - Mode of access: https://www.fs.usda.gov/ (accessed 24 February 2020).

U.S. Department of the Interior. - Electronic text data. Mode of access: https:/www.doi.gov (date of access: 24.02.2020). - Title from screen.

U.S. National Land Cover Database. Earth Resources Observation and Science (EROS) Center. Electronic text data. - Mode of access: https:// www.usgs.gov/centers/eros/science/nationalland-cover-database?qt-science_center objects $=0 \#$ qt-science_center_objects (date of access: 24.02 .2020$)$. - Title from screen.

\section{REFERENCES}

Dzhingaradze V.Z. Ekonomicheskaya istoriya SShA [Economic History of the United States]. Moscow, Vyssh. shk. Publ., 1973. 159 p.

Smit V.B., Darr D. Lesnoe khozyaystvo SShA v faktakh $i$ istoricheskoy dinamike [U.S. Forestry in Facts and Historical Dynamics]. [S. 1.], [s. n.], 2005. 40 p.

Robinson N. Pravovoe regulirovanie prirodopolzovaniya i okhrana okruzhayushchey sredy v SShA: per. s angl. [Legal Regulation of Nature Management and Environmental Protection in the United States. Translated from English]. Moscow, Progress Publ., $1990.528 \mathrm{p}$.

Rodin I.K., Minat V.N. K probleme otsenki rynochnoy stoimosti zemli [On the Problem of Assessing the Market Value of Land]. Donetskie chteniya 2018: obrazovanie, nauka, innovatsii, kultura $i$ vyzovy sovremennosti: materialy III Mezhdunar. nauch. konf. [Donetsk Readings 2018: Education, Science, Innovation, Culture and Modern Challenges. Proceedings of the $3^{\text {rd }}$ International Scientific Conference]. Donetsk, Izd-vo DonNU, 2018, pp. 337-339.

Estoll R. Geografiya Soedinennykh Shtatov Ameriki: per. s angl. [Geography of the United States of America. Translated from English]. Moscow, Progress Publ., 1977. 429 p.

Clawson M. Land for Americans. Chicago, Rand McNally, 1963.396 p.

C1awson M. Land for the Future. New York, MeGraw Hill, 1957.420 p.

Clawson M. The Land System of the United States. Nebraska, University of Nebraska, 1968. 460 p.

Kellogg R.L., TeSelle G.W., Goebel J.J. Highlights from the 1992 National Resources Inventory. J. Soil and Water Conserv., 1994, vol. 49, no. 6, pp. 521-527.

Landsberg G.G., Fishman L.L., Fischer J.L. Resources in America's Future. New York, [s. n.], 1959. $712 \mathrm{p}$.

Lindstrom M.J., Schumacher T.E., Blecha M.L. Management Considerations for Returning CRP Lands to Crop Production. J. Soil and Water Conserv., 1994, vol. 49, no. 5, pp. 420-425.

Sturdevant S.K. Toward a Federal Land Information Systems: Experiences and Issues. US Geol. Surv. Bull., 1989, no. 1852, pp. IV, 1-15.

Taylor C.R., Smith H.A., Johnson J.B., Clark R.T. Aggregate Economic Effects of CRP Lands Returning to Production. J. Soil and Water Conserv., 1994, vol. 49, no. 5, pp. 473-480.

White G., Foscue E., McKnight T. Regional Geography of the United States. New York, [s. n.], 1977. 408 p.

Bureau of Land Management. URL: https:/www. blm.gov/ (accessed 24 February 2020).

National Park Service. URL: https://www.nps.gov/ index.htm (accessed 24 February 2020).

Statistical Abstract of the United States 1953-2000. Washington, U.S. Government Printing Office, 1954-2001. URL: https://books.google.ru/ books?id=YkXjuVR9iN8C\&hl=ru (accessed 24 February 2020).

U.S. Census of Agriculture 1954-2000. United States. Bureau of the Census. Washington, U.S. Government Printing Office, 1957-2003. URL: https://books.google.ru/books?id=sgNIAQA AIAAJ\&hl=ru\&source $=$ gbs_navlinks_s (accessed 24 February 2020).

U.S. Department of Agriculture: An Official Website of the United States Government, Economic Research Service: Major Land Uses in the 
United States, 1970-2001. URL: https://www. usda.gov/ (accessed 24 February 2020).

U.S. Department of Agriculture: National Agricultural Statistics Service, 1936-2001. URL: https:/www.nass.usda.gov/Publications/ Ag_Statistics/ (accessed 24 February 2020).

U.S. Department of Agriculture: United States Forest Service (USFS). URL: https://www.fs.usda.gov/ (accessed 24 February 2020).
U.S. Department of the Interior. URL: https:// www.doi.gov/ (accessed 24 February 2020).

U.S. National Land Cover Database. Earth Resources Observation and Science (EROS) Center. URL: https://www.usgs.gov/centers/ eros / science/national-land-coverdatabase?qt-science_center_objects $=0 \#$ qtscience_center_objects (accessed 24 February 2020).

\section{Information About the Author}

Valerij N. Minat, Candidate of Sciences (Geography), Associate Professor, Department of Economics and Management, Ryazan State Agrotechnological University named after P.A. Kostychev, Kostycheva St., 1, 390044 Ryazan, Russian Federation, minat.valera@yandex.ru, https://orcid.org/0000-0002-8787-4274

\section{Информация об авторе}

Валерий Николаевич Минат, кандидат географических наук, доцент кафедры экономики и менеджмента, Рязанский государственный агротехнологический университет им. П.А. Костычева, ул. Костычева, 1, 390044 г. Рязань, Российская Федерация, minat.valera@yandex.ru, https://orcid.org/0000-0002-8787-4274 